\title{
OS DISCURSOS PRESENTES NA FORMAÇÃO DE PROFESSORES DE HISTÓRIA E OS SEUS EFEITOS NA CONSTRUÇÃO DAS IDENTIDADES DISCENTES
}

\section{DISCOURSES PRESENT IN THE EDUCATION OF HISTORY TEACHERS AND THEIR EFFECTS ON THE CONSTRUCTION OF STUDENT IDENTITIES}

\author{
lamara da Silva Viana ${ }^{1}$ \\ Pontifícia Universidade Católica do Rio de Janeiro - PUC-RIO \\ Alice Mabel Prates Monteiro² \\ Pontifícia Universidade Católica do Rio de Janeiro - PUC-RIO
}

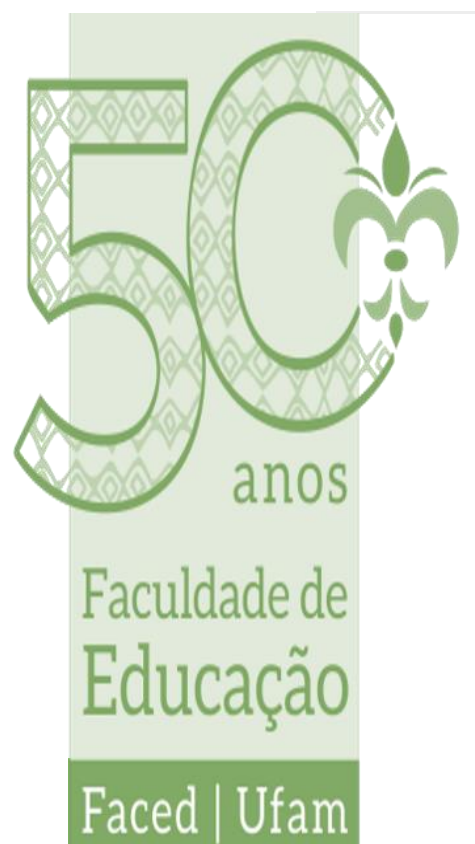

\section{Resumo}

Este artigo tem como objetivo evidenciar a forma como o discurso histórico escolar contribui para o processo de elaboração e reelaboração identitária dos estudantes. Para isso, compreende-se o conceito de representação como central nos processos de identificação, subjetivação e incorporação ativa do imaginário social. Partindo das perspectivas teóricas proporcionadas pela Teoria Social do Discurso e pela Nova História Cultural, aliada aos estudos sobre o Ensino de História, é intenção salientar o potencial performativo do discurso na formulação e aplicação de uma narrativa histórica descentrada, capaz de fornecer subsídios para uma reflexão crítica pelos discentes acerca da realidade e abrir, assim, possibilidades para atitudes transformadoras.

Palavras-chave: Discurso Histórico Escolar; Representação; Identidade.

\section{Abstract}

This article aims to point out how historical discourse in schools contributes to the student body's process of identity creation and re-creation. In this view, the concept of representation is considered a key element in the processes of identification, subjectivation and active incorporation of the

\footnotetext{
1 Professora do Departamento de História da PUC-Rio. Pós doutora pelo PPGHC/UFRJ. ORCID: https://orcid.org/0000-0002-7290-4995. E-mail: ia.sviana@gmail.com.

${ }^{2}$ Mestranda em História Social da Cultura pela PUC-Rio e Graduada em História (Licenciatura e Bacharelado) pela PUC-Rio. ORCID: https://orcid.org/0000-00018804-5577. E-mail: alicemabelprates@yahoo.com.br.
} 


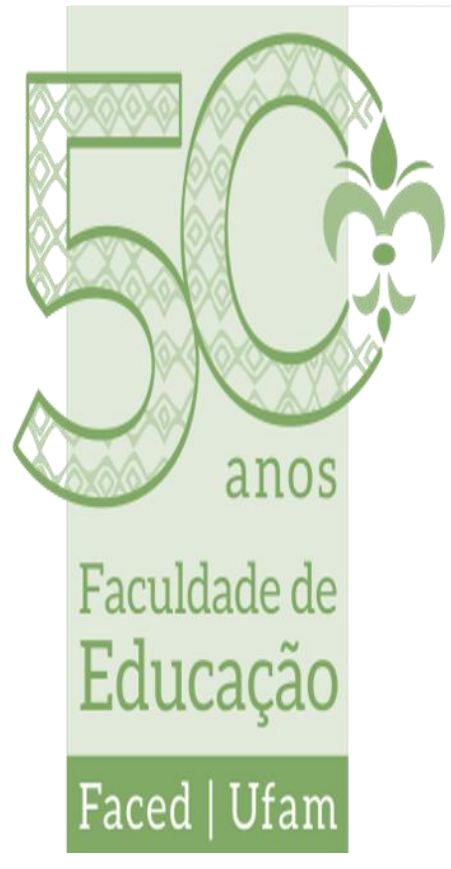

social imaginary. Starting from the theoretic perspective proportioned by the New Cultural History, summed with studies on history teaching, the main intention is to reveal the performance potential of discourse in the formulation and execution of an uncentered historical narrative, capable of providing means for a critical reflection by students about reality and, thus, opening possibilities for changes in behavior.

Keywords: School's Historical Discourse; Representation; Identity.

\section{INTRODUÇÃO}

A educação brasileira alicerçou-se de forma desigual. A Independência (1822), por um lado, possibilitou a existência de instituições de ensino, mas por outro, eram poucos aqueles que verdadeiramente tinham acesso ao conhecimento e às letras. Somado a isso, leis foram criadas com o escopo da negação: escravizados não poderiam frequentar os bancos escolares ${ }^{3}$. Dessa forma, construía-se um projeto de nação que estabelecia, em seu corpo legislativo e em suas práticas políticas, quem poderia deter o poder do conhecimento letrado e, com isso, ditar as normas do país enquanto elite privilegiada. Contudo, a história que é feita e contada com base nos discursos das elites e das ditas "grandes personalidades" há muito tempo já não satisfaz" ${ }^{4}$. A agência dos grupos subalternos deve ser levada em consideração se quisermos construir uma historiografia e um saber histórico escolar que cheguem mais perto de representar a realidade.

Nesse sentido, o domínio do ler e do escrever poderia significar liberdade - nas suas mais diversas possibilidades de interpretação - para escravizados africanos, seus descendentes, libertos e pretos livres. E muitos deles sabiam, o que se reflete na carta escrita pelos libertos de Vassouras, em 19 de abril de 1889, ao

\footnotetext{
${ }^{3}$ Sobre diferentes experiências de educação, letramento, alfabetização, escolas e ensino na sociedade escravista ver a coletânea: MAC CORD, Marcelo; ARAÚJO, Carlos Eduardo; GOMES, Flávio (orgs). Rascunhos cativos. Educação, escolas e ensino no Brasil escravista. Rio de Janeiro: Faperj; 7 Letras, 2017.

4 O movimento historiográfico da Escola dos Annales, cujo periódico Annales d'historie économique et sociale foi fundado em 1929, por Lucien Febvre e Marc Bloch, contestou o fazer histórico do final século XIX e início do XX, com grande foco político e cronológico, em prol de uma escrita que levasse em conta os aspectos mentais e culturais dos diversos setores sociais e entendesse a história como problema, em vez de narrativa linear.
} 


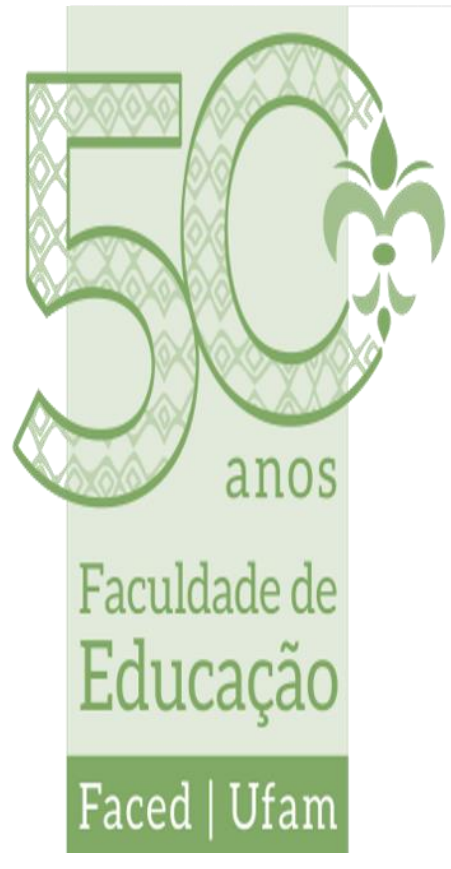

exigirem acesso à educação para seus filhos. Agiam, e não somente regiam o sistema excludente, ao requerer, para seus descendentes, acesso ao letramento. Um documento escrito e assinado por onze libertos $!^{5}$. Um novo cenário fora desenhado a partir da Constituição de 1988, tendo a Educação Básica dimensão fundante da cidadania $^{6}$, já que constitui locus importante de socialização, reflexão, aprendizado e formação de subjetividade das crianças e adolescentes $^{7}$. Assim como a esfera macrossocial, o ambiente escolar abriga múltiplas vozes e é estruturado por relações de poder, que vão desde a relação entre alunos, até a conexão destes com o quadro de professores(as), funcionários(as) e pela comunidade ao redor. Nesse contexto, o espaço da sala de aula atua como lugar particular e privilegiado de troca e compartilhamento dos conhecimentos e vivências pessoais.

Particularmente, a aula de História constitui momento fundamental para refletir a respeito de nossa experiência como seres humanos e cidadãos, vivida e escrita no tecer conflituoso das relações sociais. Isso porque, ao lidar com situações das mais plurais, subjetividades, concepções de mundo, grupos culturais, espaços e representações sociais, que permitem uma ampliação da percepção de mundo, a disciplina desmistifica o perene e evidencia o potencial transformador do ser humano. Não cabe, assim, uma interpretação da escola e da sala de aula como locais neutros ou imparciais, visto que as disputas de poder ocorrem desde a elaboração do currículo ${ }^{8}$ formal até as relações cotidianas de ensino-

5 VIANA, lamara da Silva; GOMES, Flávio dos Santos \& RIBEIRO NETO, Alexandre. "Escritos insubordinados entre escravizados e libertos no Brasil". Estudos Avançados, volume 33, Instituto de Estudos Avançados/USP, 2019, pp. 55-177.

${ }^{6}$ Artigo 205 da Constituição Federal.

7 Diretrizes Curriculares Nacionais da Educação Básica, 2013.

8 Reflexões acerca do currículo escolar de História tem crescido quantitativa e qualitativamente, dentre os quais destacamos: ABUD, Katia. Currículos de História e políticas públicas: os programas de História do Brasil na escola secundária. In: O Saber Histórico na Sala de Aula. BITTENCOURT, Circe (org.) 12. ed. 3a . reimpressão. São Paulo: Contexto, 2017; BITTTENCOURT, Circe. Capitalismo e cidadania nas atuais propostas curriculares de História. IN: O Saber Histórico na Sala de Aula. Circe Bittencourt (org.) 12. ed. 3a . reimpressão. São Paulo: Contexto, 2017; Ensino de História: fundamentos e métodos. 4. ed. São Paulo: Cortez, 2011.; GABRIEL, Carmem. Currículo de História. In: Dicionário de 


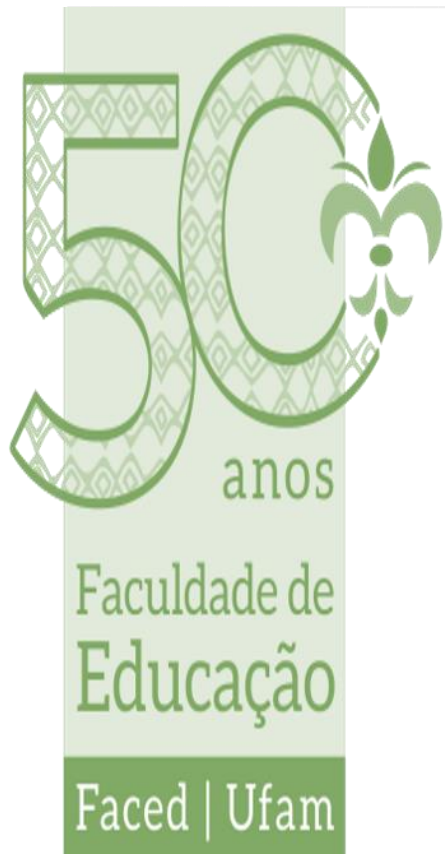

aprendizagem, nas quais entram em cena o currículo oculto ${ }^{9}$. Sobre isso, Foucault afirma:

A educação, embora seja, de direito, o instrumento graças ao qual todo indivíduo, em uma sociedade como a nossa, pode ter acesso a qualquer tipo de discurso, é bem sabido que segue, em sua distribuição, no que permite e no que impede, as linhas que são marcadas pela distância, pelas oposições e lutas sociais (FOUCAULT, 2014, p. 41).

No Brasil, as oposições, tensões e distanciamentos perpassam sua construção enquanto nação. Os diferentes grupos sociais forjados a partir do mosaico cultural desde a colonização que teve por base etnias europeias, africanas e indígenas construíram hierarquizações diversas: econômicas, sociais, culturais e também fenotípicas. É ao longo da prática educacional que os estereótipos socioculturais são frequentemente edificados, reproduzidos e ressignificados. No contraponto, o ambiente escolar pode apresentar-se também como lugar político e campo privilegiado de discussão, com capacidade para ser um foco contra-hegemônico e democrático, posto contribuir para a inserção dos jovens na sociedade, sofrendo também, por seu turno, influência desta a todo momento.

Importa ressaltar o progresso institucional referente à criação da Lei 10.639/2003, que incluiu no currículo oficial das Redes de Ensino do país a obrigatoriedade da temática "História e Cultura Afro-Brasileira", além de dar outras providências. Essa lei modificou o artigo 26 da Lei de Diretrizes e Bases da Educação de 1996, incluindo, posteriormente, pela lei 11.645, também os indígenas e suas culturas ${ }^{10}$. Conquista de diferentes movimentos sociais e do

Ensino de História. Rio de Janeiro: FGV Editora, 2019.; GIMENO SACRISTAN, J. "Currículo: os conteúdos do ensino ou uma análise da prática?" In: GIMENO SACRISTAN, J. y PÉREZ GOMES, A. I. Compreender e transformar o ensino. Porto Alegre: Artmed, 1998, $4^{\mathrm{a}}$ ed. - pp. 119-148.

${ }^{9}$ Saberes e valores ensinados de forma implícita, a partir de comportamentos, rituais e prática sociais. Não entram no currículo formal.

10 Sobre a lei 10.639 existem muitos estudos significativos, dentre os quais destacamos: ALBERTI, Verena. Algumas estratégias para o ensino de história e cultura afro-brasileira. In: Ensino de História e Culturas Afro-brasileiras e indígenas. PEREIRA, Amilcar Araujo; MONTEIRO, Ana Maria (org.). Rio de Janeiro: Pallas, 2013. 


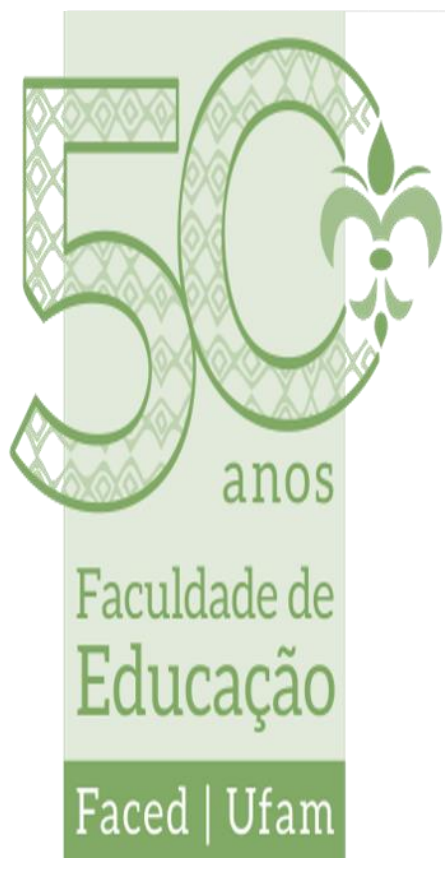

movimento negro, essa inclusão caracteriza mais uma alteração e recriação de conteúdos curriculares frente às demandas socioculturais e representa um marco reconhecido entre os pesquisadores educacionais de um avanço na direção de um ensino menos racista, ou melhor, antirracista.

Além disso, vale também destacar os Temas Transversais dos Parâmetros Curriculares Nacionais (1998), dentre eles a seção de Pluralidade Cultural, bem como as Diretrizes Curriculares Nacionais Gerais da Educação Básica (2013), do Ministério da Educação, em parceria com a Secretaria de Educação Básica. O subtítulo Diversidade e Inclusão, dentre seus objetivos gerais, busca justamente atuar sobre as representatividades sociais na educação, à luz dos novos parâmetros sociais contemporâneos. Esses direcionamentos conferem suporte legal para pesquisas que têm como foco os currículos informal e oculto, ainda pouco discutidos academicamente.

Neste artigo, a história da população negra no Brasil oferece subsídios para a reflexão central do texto: a importância dos professores no processo de elaboração e reelaboração identitária dos discentes. Se a educação era uma questão relevante para africanos e seus descendentes na sociedade escravista, como isso se refletiu no período pós-emancipação? Além disso, se às pessoas negras foi negado por tanto tempo o acesso ao conhecimento e ao poder, isso deixou marcas que até hoje podem ser vistas em diversas estatísticas do país. Segundo dados do IBGE de 2014, apesar da população negra constituir maioria da população, ela possui uma renda familiar per capita menor do que a média do país. Além disso, os números referente às taxas de desemprego, analfabetismo e evasão escolar são maiores se comparadas aos da população branca'11. Como é possível, então, construir um discurso

11 Este tópico será retomado no decorrer do artigo com mais detalhes, mas para acesso aos números, conferir TOKARNIA, Mariana. "Educação reforça desigualdades entre brancos e negros, diz estudo". Brasília, Agência Brasil, 18/11/2016. 


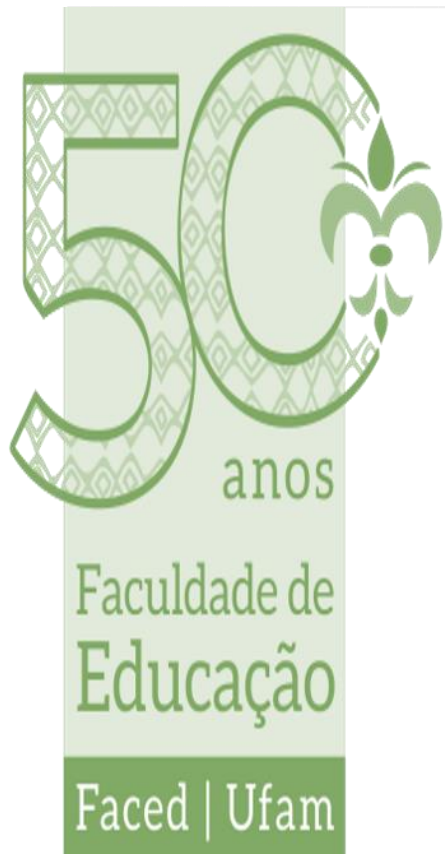

histórico escolar representativo, que inclua essa população na narrativa contada e estimule a permanência escolar e a recuperação de uma autoestima social?

\section{TEORIA SOCIAL DO DISCURSO: REPRESENTAÇÃO, IDENTIDADES E DIFERENÇAS}

O linguista Norman Fairclough compreende discurso como prática social de construção de significado, ou seja, como uma forma de agir no âmbito social - simultaneamente ação e representação -, tendo em vista ser por meio dele que as pessoas interagem entre si e com o mundo. Sendo, pois, o fenômeno discursivo síntese indissociável da relação dual entre estrutura simbólica, de cunho linguístico e psicológico, e experiências sociais. Segundo o autor,

O discurso contribui para a constituição de todas as dimensões da estrutura social que, direta ou indiretamente, o moldam e o restringem: suas próprias normas e convenções, como também relações, identidades e instituições que lhe são adjacentes. O discurso é uma prática, não apenas de representação do mundo, mas de significação do mundo, constituindo e construindo o mundo em significado (FAIRCLOUGH, 2001, p.91).

Fairclough confere três efeitos construtivos ao discurso: 1) construção das identidades sociais; 2) construção das relações sociais entre as pessoas; e 3) construção dos sistemas de conhecimento e de crença. Particularmente, é sobre o primeiro efeito que este artigo se edifica, traçando relações de influência com o segundo e o terceiro, associados aqui ao ambiente escolar e ao conhecimento histórico, respectivamente. A construção de significados nessa estrutura ocorre por meio de um embate polifônico e assimétrico, dentro de um contexto social, histórico e

SALDANHA, Paulo. "4 em cada 10 jovens negros não terminaram o ensino médio". Brasília, Folha de São Paulo, 01/09/2019. Disponível em $<$ https://www1.folha.uol.com.br/educacao/2019/09/4-em-cada-10-iovens-negrosnao-terminaram-o-ensino-medio.shtml>. Acesso em 23 mai. 2020; e RAUPP, Eric. "Pesquisa aponta grande desigualdade entre brancos, negros e pardos na educação básica" [online]. Correio do Povo, R7, 19/06/2019. Disponível em $<$ https://www.correiodopovo.com.br/not\%C3\%ADcias/ensino/pesquisa-apontagrande-desigualdade-entre-brancos-negros-e-pardos-naeduca\%C3\%A7\%C3\%A3o-b\%C3\%A1sica-1.346361>. Acesso em 23 mai. 2020. 


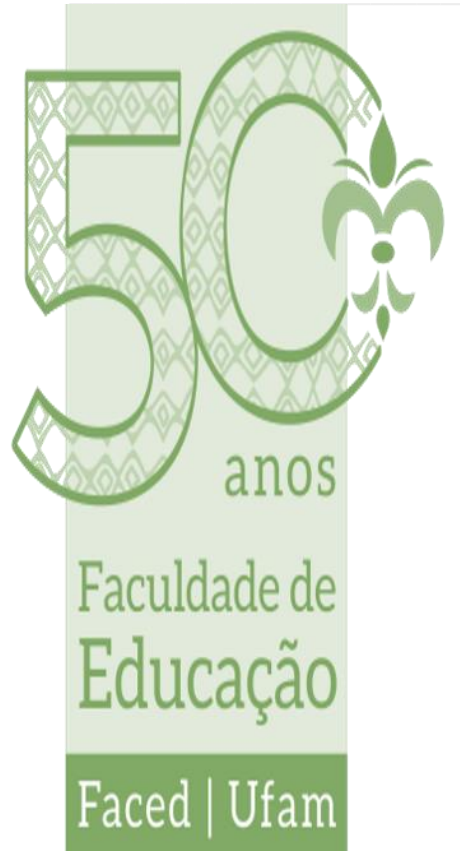

cultural amplo. Nesse sentido, estudar o discurso implica analisar como os sujeitos que o detém, ou não, constroem sua realidade.

A estrutura simbólica que agrega os conceitos classe social, raça, gênero, sexualidade, deficiência, profissão, religião, idade, nacionalidade, nível educacional, entre outros, molda relações de poder de maior ou menor grau entre o sujeito que fala, e seu interlocutor, afetando sua recepção e reconhecimento pela sociedade. O discurso é, assim, sempre contextualizado cultural, política e historicamente. Contudo, relações de poder não são estáticas; elas mudam e se transformam face às ações humanas de resistência, sejam sutis, sejam poderosas, em uma relação em que as experiências não sejam subestimadas em prol de um conceito estruturante, mas que também não se menospreze o poder do discurso enquanto ferramenta de controle social. E, nesse sentido, como analisar os diferentes discursos que se constroem nos espaços escolares, de modo geral, e na sala de aula, de modo específico? Em que medida as construções discursivas de professores podem ou não promover uma educação democrática, bem como identidades sociais significativas entre seus educandos?

O discurso, enquanto prática social simbólica e atitudinal, é mecanismo de construção e reconstrução de significados no mundo. Ancorado na linguagem, é também por meio dele que as identidades e as diferenças ganham sentido e são formuladas e reformuladas. Assim, as identidades, ou seja, as projeções do "eu" no mundo, são construídas por meio da dupla face social/simbólica. Isso significa afirmar que identidade e diferença são conceitos relacionais e culturais, construídos no bojo das diversas sociedades ao longo do tempo, e não podem, portanto, ser falsamente interpretados como naturais ou transcendentais, fatos dados e acabados da vida. Segundo Silva (2000, p. 86),

As chamadas interpretações biológicas são, antes de serem biológicas, interpretações, isto é, elas não são mais do que a imposição de uma matriz de significação sobre uma matéria que, sem elas, não tem qualquer significado. Todos os essencialismos são, assim, culturais. Todos os essencialismos 


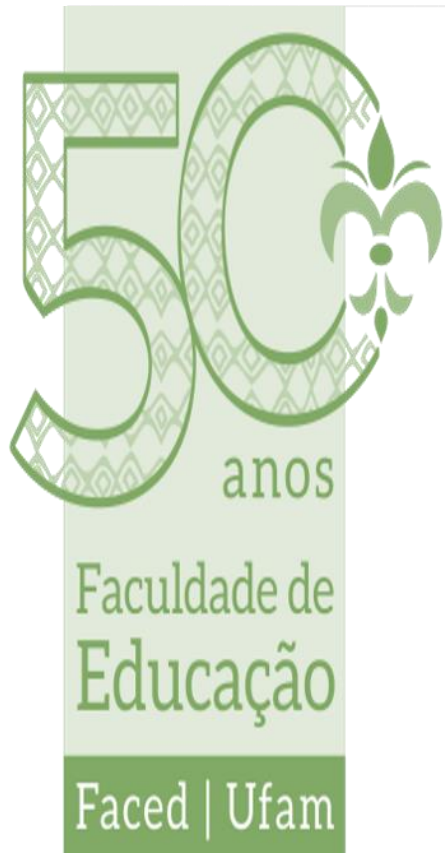

nascem do movimento de fixação que caracteriza o processo de produção da identidade e da diferença (SILVA, 2000, p. 26).

Nesse sentido, as interpretações acerca dos indivíduos que formam a sociedade brasileira - e suas diferentes e diversas etnias -, com base na sociedade escravista pretérita, se reflete em uma estrutura discursiva de poderes históricos, marcada por sistemas de significação instáveis. É característica intrínseca do signo ser adaptável, mutável. Dessa forma, se os discursos são marcados pela sua constante plasticidade, seus produtos, dentre eles a identidade e a diferença, os quais dependem dessa mesma estrutura, também o são. Como afirma Tomaz Tadeu da Silva, especialista em teoria educacional crítica, "somos dependentes, neste caso, de uma estrutura que balança" (SILVA, 2000, p. 80).

A identidade, assim, só faz sentido dentro de uma cadeia de diferenciação linguística/social sustentada por um sistema de exclusão ${ }^{12}$. A construção da identidade e da diferença realiza-se a partir de representações, que atuam "simbolicamente para classificar o mundo e nossas relações no seu interior" (HALL, 1997a apud SILVA, 2000, p. 8). Numa perspectiva pós-estruturalista, a representação incorpora todas as características instáveis e ambíguas do discurso, como qualquer sistema de significação. Estando sujeita às relações de poder sociais e seu caráter arbitrário. Modelos são construídos e estabelecidos. Fugir a essas representações coletivas, subestabelecidas inconscientemente, ocasiona uma série de sofrimentos e culpabilidades advindos de julgamentos internos e externos sobre uma ilusória falha do ideal representativo. Os sistemas de classificação sociais determinam modelos de representação, contudo, contestação e resistência se colocam. E nesse cenário, a repetição de representações das diferentes identidades torna-se inteligível.

Para que as identidades possam ser posições assumíveis pelo indivíduo é necessário que, além de ser visto numa

12 Argumento de Judith Butler, parafraseado por Stuart Hall. Para mais detalhes ver Silva, 2000, p.129. 


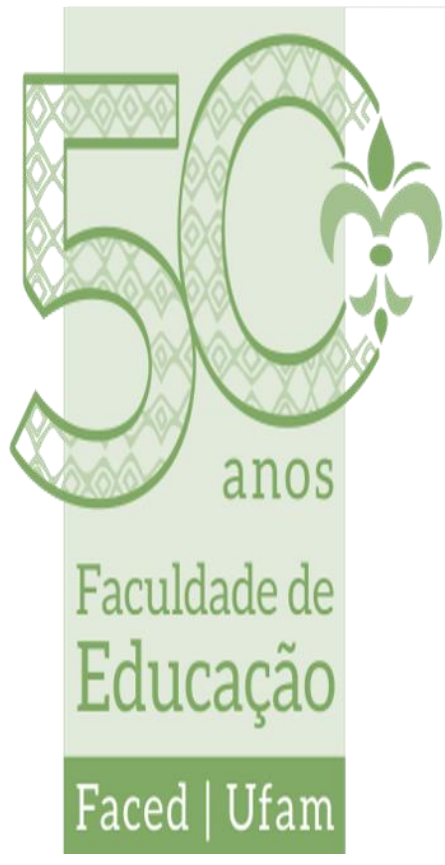

determinada classificação imposta por outros, o próprio sujeito se veja em tal posição, por meio de processos de assimilação, sujeição e investimento pessoal. Sendo, pois, necessária a presença de um elemento psíquico subjetivo, sem o qual nenhum sistema disciplinar teria o efeito controlador desejado, pois "quaisquer que sejam os conjuntos de significados construídos pelos discursos, eles só podem ser eficazes se eles nos recrutam como sujeitos" (SILVA, 2000 , p. 55). Stuart Hall (2000, p. 112), teórico cultural jamaicano, define essa internalização como uma costura entre o psíquico e o discursivo, ou seja, uma articulação contingencial entre o sujeito e o social. Por lidar com características psíquicas e inconscientes, as identidades não constituem decisões racionais e ordenadas, compondo "pontos de apego temporário às posições-de-sujeito que as práticas discursivas constroem para nós" (HALL In: SILVA, 2000, p. 112). Pode existir discrepâncias entre o nível coletivo e o nível pessoal, além de negociações constantes entre identidades conflitantes.

O corpo atua, nesse sentido, como parte do processo de estabelecimento de fronteiras, ao definir "quem somos" e, por consequência, nos distinguir dos outros. Ele é uma esfera importante de projeção de significados. Exteriorizamos quem somos por meio de comportamentos, roupas, expressões linguísticas, uso de determinados objetos e acessórios, comida, hábitos etc. Também é por meio dele que sofremos as represálias caso apresentemos alguma fuga dos padrões identitários estabelecidos, concretizados em discriminações muitas vezes baseadas em condições fenotípicas, como a cor da pele.

Quando pomos em dúvida "quem somos", uma crise de identidade acontece: "esta perda de um 'sentido de si' estável é chamada, algumas vezes, de deslocamento ou descentração do sujeito" (HALL, 2011, p. 9). A chamada crise de identidade também pode ser vivida coletivamente, em um nível social mais amplo. Essa fissura no status quo, que se supunha fixo e coerente, envolve diversas áreas da sociedade e possibilita o aparecimento de 


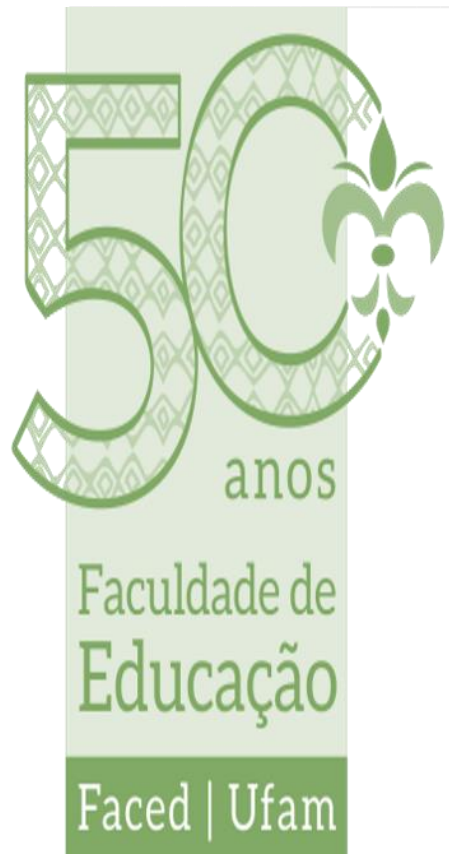

múltiplos questionamentos e incertezas alavancadas por novas experiências individuais e coletivas.

Sabemos, com base nas reflexões feitas até aqui, que as identidades, ou formas de "narrativização do eu" (HALL In: SILVA, 2000 , p. 109) coerentes e objetivas, são frutos de construções sociais inventadas. A partir da segunda metade do século $X X, 0$ mundo vivenciou uma série de transformações econômicas, políticas e culturais que protagonizaram um momento de deslocamento das estruturas simbólicas de sustentação da sociedade moderna, "abalando os quadros de referência que davam aos indivíduos uma ancoragem estável no mundo social" (HALL, 2011, p. 7).

Mais especificamente, dois elementos passaram a ser fortemente questionados à luz das teorias construtivistas, promovidas pelos movimentos sociais, tais como o movimento feminista e o movimento negro, que compreenderam o indivíduo como construção discursiva e cultural, exposto às contingências históricas das sociedades. São os elementos: a presença de uma essência identitária inata, constituída biologicamente, e o protagonismo da razão consciente, a partir da descoberta freudiana do inconsciente. ${ }^{13}$ Esses questionamentos contribuíram para deteriorar ainda mais a concepção lluminista de sujeito, em contestação já desde o início do século XX, na qual o homem era entendido como um ser racional, centrado, indivisível, hermético e singular, cuja identidade era mantida essencialmente a mesma durante toda a sua vida, apenas desenvolvendo princípios e características já presentes desde o nascimento.

$O$ que era então tradicionalmente restrito e coerente, na modernidade tardia assumiu caráter amplo e transitório. "As sociedades modernas são, portanto, por definição, sociedades de mudança constante, rápida e permanente" (HALL, 2011, p. 15). As identidades singulares norteadoras, relacionadas, por exemplo, às nações, ou aos partidos políticos, se transformaram em identidades múltiplas, contraditórias e deslocadas. Esse é o caráter da 


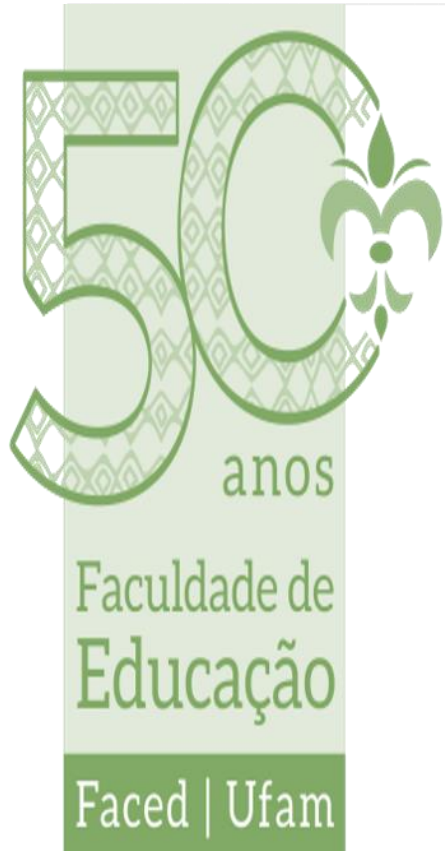

modernidade, levado até seu extremo nas sociedades da modernidade tardia, as quais "[...] são caracterizadas pela 'diferença'; elas são atravessadas por diferentes divisões e antagonismos sociais que produzem uma variedade de diferentes 'posições de sujeito' - isto é, identidades - para os indivíduos” (HALL, 2011, p. 18).

A partir do exposto acima, consideramos/vivenciarmos uma "crise de identidade". A incerteza e a pluralidade de centros identitários não combinam com os modelos institucionais tradicionais, tais como os de nação, linhagem, família, partido, igreja, entre outros, que tentam sedimentar padrões de comportamento restritos. Incerteza e pluralidade, assim, causam incômodo, balançam as estruturas sociais, formando uma comunidade simbólica imaginada ${ }^{14}$, construída por práticas sociais e relações de poder, cujo objetivo é alimentar sentimentos de lealdade, coesão e identificação.

Para atingir esse fim, a afirmação dessa identidade nacional precisou historicamente reprimir diferenças identitárias sociais que ameaçassem a formação de um conjunto harmônico, tais como aquelas relacionadas a classe, raça, gênero e sexualidade. Esse processo não foi feito de forma pacífica, mas sim através da supressão violenta da diferença, obedecendo a critérios hierárquicos de cunho hegemônico, tanto simbolicamente - com repressão a movimentos culturais, criminalização de manifestações identitárias postas como imorais - quanto fisicamente - com perseguição, agressão e morte de indivíduos que manifestassem publicamente comportamentos externos à norma ${ }^{15}$. E, como destacamos no início

\footnotetext{
${ }^{14}$ Sobre a formação das identidades nacionais, ver "Comunidades imaginadas", de Benedict Anderson.

15 Cito como exemplo o Decreto no 847 , de 11 de outubro de 1890 , conhecido como Código Penal dos Estados Unidos do Brazil, que inseria a capoeira manifestação cultural representativa da cultura negra - como forma de "vadiagem" e seus praticantes poderiam ser punidos com dois a seis meses de prisão. Para saber mais a respeito consultar ROESLER, Átila da Rold. Sobre a vadiagem e o preconceito nosso de cada dia. Justificando, 9 ago. 2016, site. Disponível em $<$ http://www.justificando.com/2016/08/09/sobre-a-vadiagem-e-o-preconceitonosso-de-cada-dia/>. Acesso em 25 nov. 2018.
} 


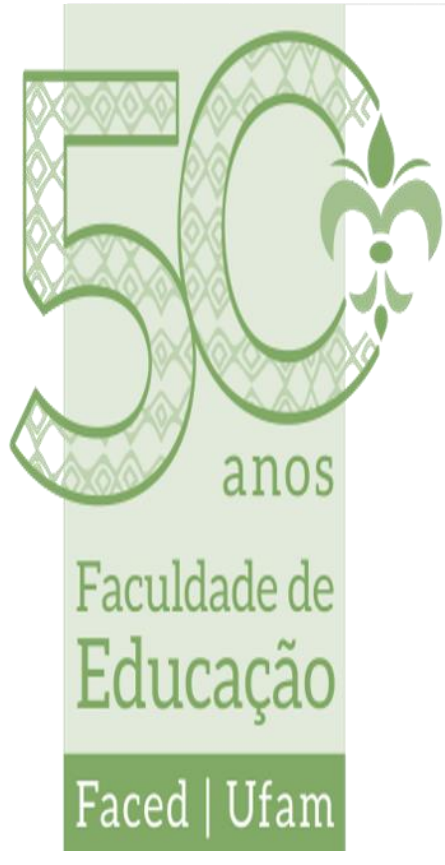

deste artigo, por meio de um processo historicamente construído, a partir da escravização de diferentes povos africanos e indígenas.

Diferenças identitárias nunca deixaram de existir. No entanto, elas foram relegadas a um papel secundário dentro da construção do Estado Brasileiro. O que se observa atualmente nas sociedades da modernidade tardia é a fragmentação desse padrão identitário nacional, perante a emergência de múltiplas formas de identificação. Diferenças sociais obscurecidas durante décadas em prol de um projeto estatal totalizante estão agora reivindicando seu lugar de articulação ao lado da identidade nacional, provocando justamente o deslocamento do nacional para o local, do unitário para o múltiplo.

\section{NORMALIZAÇÃO E PERFORMATIVIDADE}

O processo de normalização é uma forma sutil e eficaz de hierarquização social, já que consiste em eleger arbitrariamente como parâmetro uma determinada identidade, em detrimento das demais. Essa reunião de elementos positivos em uma só identidade cria, por consequência, um sentimento de falta nas marginalizadas, que é traduzido pelo apagamento da própria noção de identidade naquela considerada padrão e de constante reforço da diferença como algo negativo nas outras muitas. O elemento normalizador cria posições-de-sujeito em relação a uma regra que permanece invisível, porém poderosa: qualquer diferença do padrão é tida como um desvio, um acidente, uma marca negativa. Isso também pode ser observado nos casos da supremacia branca, heterossexual e sem deficiência e, a nível mais amplo, no caso da supremacia estadunidense e europeia dentro da esfera ocidental, quiçá mundial, com o recorrente uso da palavra "exótico" ou "atrasado", para referirse às demais culturas.

Essa tendência à normalização presente nos discursos, por meio de representações metonímicas, dentre os quais o discurso histórico escolar não escapa, é problemática por reproduzir um padrão identitário parcial, ilusório e historicamente construído em cima de relações de poder assimétricas. Solidifica hierarquias, não 


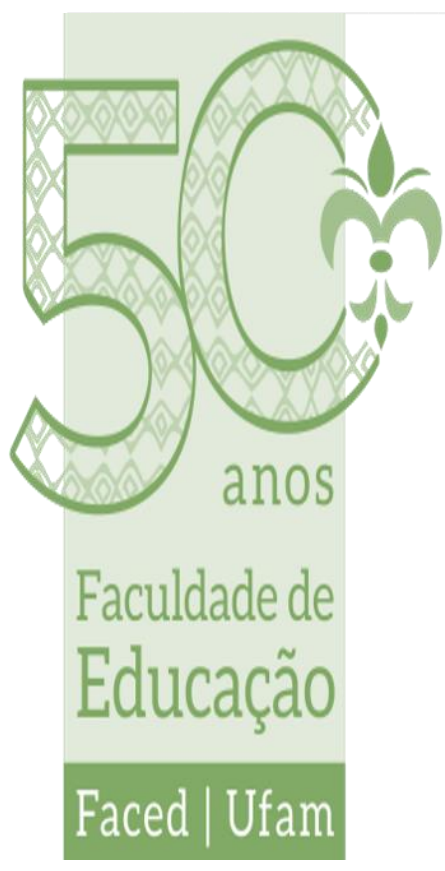

colocando as identidades hegemônicas sob a luz da alteridade, reforçando, a todo momento, um caráter desviante nas demais identidades, reafirmando-os como detentores do poder de representar e de definir aqueles que não os possuem. Assim, "questionar a identidade e a diferença como relações de poder significa problematizar os binarismos em torno dos quais elas se organizam" (SILVA, 2000, p. 83); significa, ademais, questionar os sistemas de representação que the oferecem suporte em prol de um imaginário coletivo que gire sem o estabelecimento de um ponto de referência fixo. Tal referência, aliás, deve ser a própria diferença, único elemento constante no cenário infrequente histórico/cultural.

Contudo, há dificuldades, visto que, no movimento de contestação à ordem binária, podem ser criadas novas normalizações, já que os sistemas de dominação apresentam matizes, sobreposições e esferas diferenciadas de ação. Estamos acostumados a criar padrões simplificados e maniqueístas. Como afirma Tomaz Silva, "a fixação é uma tendência e, ao mesmo tempo, uma impossibilidade" (SILVA, 2000, p. 84). A intenção então deve ser a de modificar o binarismo enquanto sistema de classificação, não apenas substituindo seus elementos, mas colocando como conceito central a contingência, a fixação temporária - se nos é permitida essa antítese - reconhecendo, assim, posições-de-sujeito e lugares de fala fronteiriços.

Para investir nessa subversão, o conceito de performatividade apresenta-se como elemento chave para essa discussão, pois apenas descrever a forma arbitrária com a qual as identidades e diferenças são construídas colabora para seu processo de solidificação social. Contornando esse problema, o conceito apresentado, primeiramente desenvolvido pelo filósofo da linguagem J. A. Austin, e, posteriormente, expandido pela filósofa feminista Judith Butler, salienta o caráter transformador do discurso ${ }^{16}$. Austin afirma que o discurso possui proposições que, ao serem constantemente ditas e repetidas, reforçam seu poder de concretude

${ }^{16}$ Sobre o conceito de performatividade, ver SILVA, 2000, p. 92-96. 


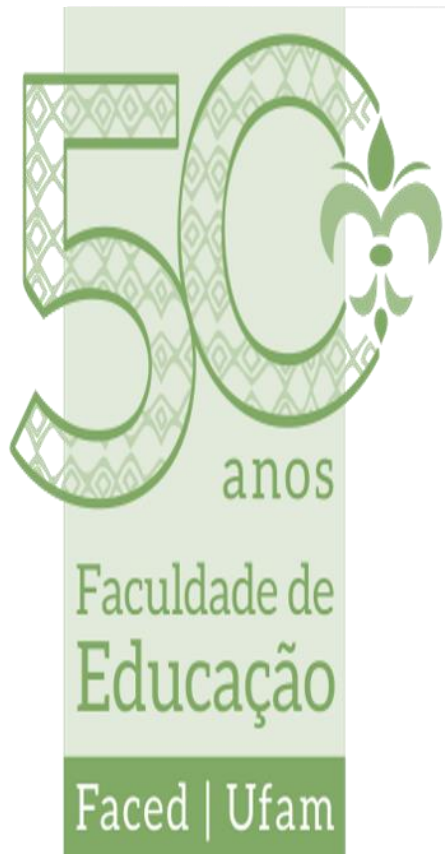

na realidade presente. Butler amplia a aplicabilidade do termo da área linguística para a área social inserindo-o na produção das identidades. Segundo a autora, a repetição de adjetivações, teoricamente com objetivo descritivo sobre determinadas características identitárias de grupos sociais, pode contribuir para 0 desenvolvimento de identificações e processos incorporativos de indivíduos com tais características, tanto positiva quanto negativamente, alavancando práticas sociais adulteradas.

Podemos usar como exemplo o cabelo cacheado do tipo crespo como constituinte da identidade negra. Ao longo do tempo criou-se, com eficácia produtiva, através da repetição, a associação entre cabelo crespo/cacheado, considerado "ruim" ou feio performatividade negativa -, e cabelo liso, considerado "bom" ou bonito - performatividade positiva. Assim, quando nos utilizamos de adjetivos pejorativos que associam o cabelo crespo/cacheado ao cabelo "ruim", o que ocorre não seria a mera descrição, mas a perpetuação discursiva da negatividade associada à identidade negra e, de forma mais ampla, ao continente africano em sua multiplicidade étnica.

Essa costura realizada entre o psíquico e o discursivo, ou seja, entre o reconhecimento de um tipo de cabelo, no espelho ou no próximo, e sua identificação subjetiva a adjetivos negativos como feio ou ruim, pode provocar danos psicológicos e identitários, inclusive resultando em processos de transformação física, como as várias opções de alisamento capilar difundidos na sociedade por meio das campanhas midiáticas e apropriadas pelas empresas na forma de diversos produtos. Mesmo que essa transformação não seja conscientemente compreendida como uma negação identitária produzida discursivamente - "se isso é ruim ou feio, logo eu não sou isso" -, tanto para si, quanto para os outros, as medidas concretas guardam efeitos às vezes radicais e dramáticos nos corpos e mentes humanos. O cabelo é apenas um dos muitos exemplos de alterações que podem assumir caráter bem mais grave e permanente, como cirurgias plásticas ou mutilações. 


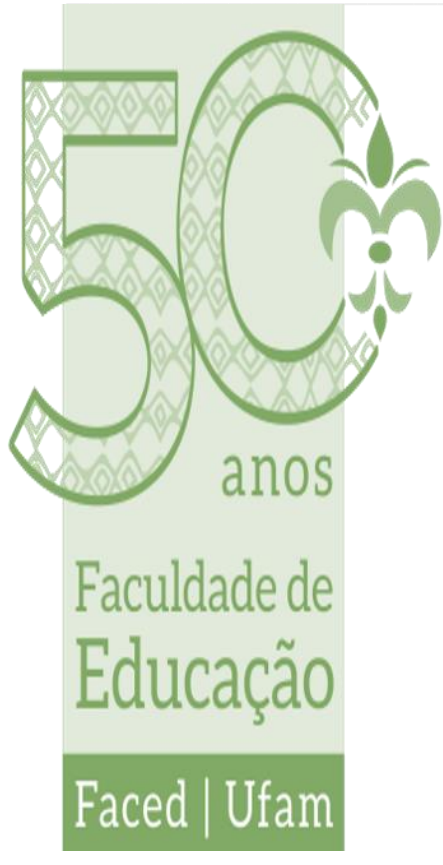

Reflexo disso é ver crianças, que ainda não tem aprimorado o seu potencial de apreensão das regras e dinâmicas sociais, pedindo o alisamento de seus cabelos aos pais - quando não são esses que tomam a iniciativa, expondo os filhos a produtos agressivos a sua saúde. Isso demonstra 0 efeito poderoso e inconsciente da performatividade do discurso na constituição psicológica dos indivíduos, que, desde cedo e, sem a reflexão consciente dos motivos sociais por trás de tal posicionamento, entendem ser negativa aquela característica física que possuem.

Da mesma forma, quando um professor se refere a determinado aluno como "burro" ou "preguiçoso", ele está ajudando a moldar posições-de-sujeito e, consequentemente, noções de identidade do próprio estudante e dos seus colegas ao redor, que assumem subjetivamente aquela posição a partir do olhar do professor. "É de sua repetição e, sobretudo, da possibilidade de sua repetição, que vem a força que um ato linguístico desse tipo tem no processo de produção da identidade" (SILVA, 2000, p. 94). Essa possibilidade de repetição acontece quando determinada adjetivação de tão recorrente se torna normalizada, assimilada como verdade pelos indivíduos, que a utilizam em outras circunstâncias, sem questionamento.

O potencial performativo do discurso, no contraponto, adquire papel transformador, quando, ao invés de contribuir para reforçar hierarquias sociais, colabora para 0 processo de interrupção e desconstrução dessas repetições. É possível extrair novas representações e construir novas identidades ao criticar esses modelos historicamente configurados. Os diferentes movimentos sociais afirmativos que buscam representações justas, por meio do resgate de símbolos identitários, do constrangimento da norma e da ênfase na positividade da diferença, são um exemplo a ser analisado.

No exemplo acima mencionado, acerca do cabelo crespo/cacheado, temos, no movimento negro das últimas décadas, uma releitura positiva. A partir disso, houve, por parte dos 


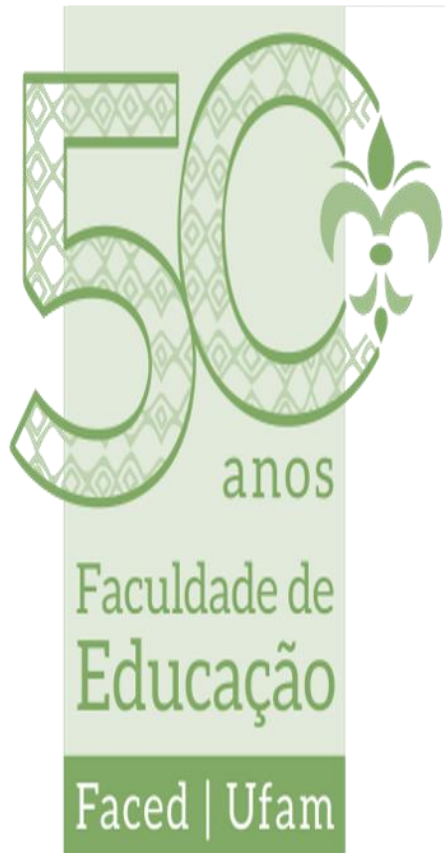

integrantes, a interrupção do vínculo entre cabelo crespo/cacheado e cabelo "ruim", bem como a valorização da beleza do cabelo afro, por meio de campanhas relacionando-o a status poderosos e belos. Atualmente, observa-se crescente mobilização social para a exibição orgulhosa dos cachos e do crespo, assimilando-os como símbolo positivo metonímico da identidade negra. Se a imposição normativa era o cabelo liso e o cabelo crespo/cacheado era considerado o "outro", marginalizado, agora essa imposição encontra-se enfraquecida e o cenário capitalista globalizado da moda abre espaço para a convivência de ambos os tipos de cabelo. Isso não significa que o processo de opressão discursiva tenha tido fim, nem que as pessoas negras de cabelo crespo/cacheado ainda não sofram com a supremacia da identidade branca, mas indica o potencial transformador que a performatividade do discurso, associada a um movimento social, possui para a alteração da realidade material e simbólica. Importa mencionar a relevância dos contrapontos às representações do status quo, principalmente ao valorizar a convivência das diferenças por meio de um discurso performativo positivo.

\section{O DISCURSO HISTÓRICO ESCOLAR EM SEU POTENCIAL PERFORMATIVO}

O discurso histórico escolar, como um tipo de discurso, abrange todas as características que o definem enquanto fenômeno discursivo. Ele tem, portanto, papel fundamental na perpetuação ou transformação de sistemas de estratificação social. Foucault nos ajuda a vislumbrar o caráter social da história, ao defender uma historiografia que coloque em diálogo prática social e estrutura simbólica, na qual os acontecimentos estudados consigam sempre gerar novas interpretações e construções narrativas (FOUCAULT, 2014). Nesse sentido, o trabalho do historiador é, por meio de fontes históricas, interpretar e construir uma narrativa sobre um certo acontecimento, à luz de sua relação com a estrutura, ou seja, com o conjunto de símbolos e significados que o sustentam e o legitimam, 


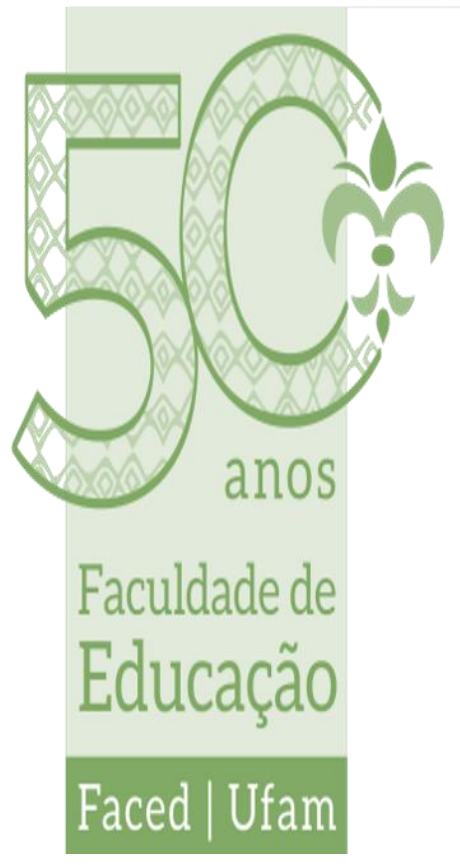

frente a determinada sociedade, em um determinado período de tempo.

O discurso histórico escolar17, até a ditadura militar, produziu uma narrativa eminentemente calcada nas noções de tradição, família e nação. Com certa alteração nos atores históricos escolhidos, a presença de "brasileiros célebres" (FONSECA, 2017, p. 60) foi constantemente invocada como representação de valores heroicos que valiam a pena ser exaltados. Esses atores eram majoritariamente bastiões de uma ou mais identidades dominantes na hierarquia social, guardando características consideradas virtuosas, associadas à masculinidade, à heterossexualidade e à branquitude.

Com base na teoria de Von Martius, sobre a mistura das três raças - branca, negra e amarela ou indígena -, o ensino de história consagrou uma ideia falsa de harmonia e democracia racial, que, na verdade, exaltava a colonização portuguesa e a cultura branca europeia, permeando-as de elementos positivos, e colocando as demais raças como "outras", portadoras de características negativas e subordinadas a um direcionamento claramente elitizado18. Dessa forma, os negros eram - e, infelizmente, muitas vezes ainda são representados no discurso histórico escolar apenas como mercadoria ou mão de obra, sempre como vítimas submissas aos seus senhores brancos, presos aos grilhões de sofrimento da estrutura escravagista. As formas de resistência à escravidão, quando abordadas, também geralmente giravam em torno dos quilombos e das manifestações violentas de luta. As múltiplas formas de resistência cultural, ou, ainda, as complexidades da sociedade escravista eram ignoradas ou tratadas de forma menos relevante, embora a historiografia da escravidão tenha produção significativamente qualificada, apresentando o negro e o escravizado como sujeito político no processo de construção histórica19.

\footnotetext{
17 Sobre as especificidades do discurso histórico escolar ver Monteiro, 2007.

18 Ver FONSECA, 2017, p. 50.

19 Sobre a historiografia acerca da escravidão e o negro e o escravizado como sujeitos políticos ver: GOMES, Flávio. Histórias de Quilombolas: mocambos e
} 


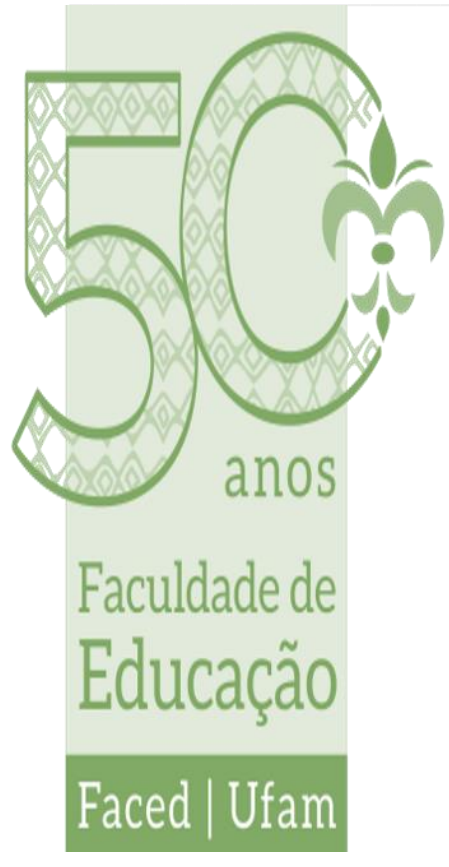

No entanto, mesmo após a publicação da Lei 10.639 , tais Histórias não abrolham no processo de elaboração do discurso histórico escolar, não existindo menção a "palavra - ou imagem sobre outros aspectos do cotidiano, como as festas, batuques, procissões, conversações ocorridas nas ruas" (FONSECA, 2017, p. 100). Essa visão reducionista, mantida e atualizada com a categoria do malandro e do vagabundo, no estudo sobre o Brasil República, fomenta uma memória coletiva, na qual a identidade negra é representada apenas ligada ao trabalho pesado e escravo, à violência e à ilegalidade do Império do Brasil.

Ora, se o estudante negro se vê repetidamente representado na narrativa histórica de forma restrita e obtusa, ou seja, se sua principal conexão com esse passado legitimador do presente é através da violência, do trabalho braçal ou da vagabundagem, e se essa visão não é contestada, logo a construção do seu "eu" - sua visão sobre si, suas possibilidades e seus limites enquanto cidadão brasileiro - será estabelecida por um processo de subjetivação inconsciente dessa realidade como norma, de acordo com o caráter performativo desse discurso.

Como consequência desse quadro, gerou-se uma espécie de baixa autoestima coletiva em todos os grupos marginalizados20, que são vistos e se veem como inferiores ou incapazes. Esse sentimento é fruto de uma construção histórica, mantida e reforçada também na forma pela qual as representações sociais são elaboradas no discurso histórico nas salas de aula brasileiras; elas são reproduzidas de forma incompleta e deturpada, em razão da falta de

comunidades de senzalas no Rio de Janeiro, século XIX. São Paulo: Companhia das Letras, 2006.; CHALHOUB, Sidney. Visões da Liberdade: uma história das últimas décadas da escravidão na Corte. São Paulo: Companhia das Letras, 1990.; REIS, João José; SILVA, Eduardo. Negociação e Conflito.; SLENES, Robert W. Na Senzala, uma flor: esperanças e recordações na formação da família escrava - Brasil Sudeste, século XIX. Rio de Janeiro: Nova Fronteira, 1999.

20 Segundo as Diretrizes Curriculares Nacionais da Educação Básica, 2013, p. 18, esses grupos marginalizados são constituídos por "pobres, mulheres, afrodescentendes, indígenas, pessoas com deficiência, as populações do campo, os de diferentes orientações sexuais, os sujeitos albergados, aqueles em situação de rua, em privação de liberdade". 


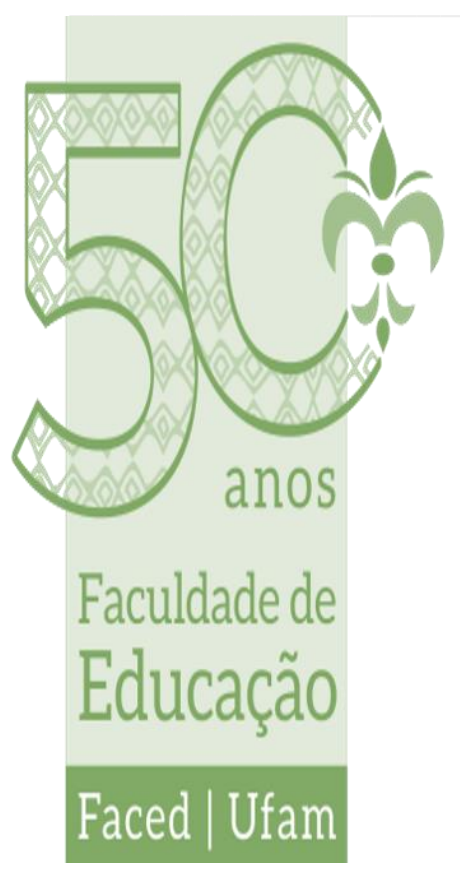

uma abordagem crítica, que evidencie que o processo de exclusão é histórico, e nunca biológico.

No estado do Rio de Janeiro, por exemplo, em pesquisa realizada pelo Ministério do Trabalho e Emprego (RAIS, 2016), a desigualdade salarial entre brancos e negros era de $69,3 \%$. Além disso, o percentual de pessoas negras ocupando profissões menos qualificadas e com menor remuneração é maior do que o de pessoas brancas. Essa desigualdade pode ser observada não só no Rio de Janeiro, como em todo o país21. Sendo a educação elemento fundamental no mundo do trabalho, os dados acerca dela também ajudam a compor o cenário negativo em relação à população negra. Segundo dados da Pesquisa Anual por Amostra de Domicílios Contínua (PNAD-contínua), embora tenha havido melhora significativa na educação brasileira, entre os anos de 2016 e 2018, as desigualdades de raça, gênero, cor e região persistem. A educação básica, obrigatória pela Constituição no Brasil, se mostrou maior entre brancos $(55,8 \%)$ do que entre pretos e pardos $(40,3 \%)$. 22 E o analfabetismo atingia, em 2018, 11,3 milhões de pessoas com 15 anos ou mais. A análise por cor ou raça para o mesmo ano mostrou que $3,9 \%$ de analfabetos, nessa mesma faixa etária, era composta por brancos. Entre as pessoas de cor preta ou parda, o percentual apresentado era de $9,1 \%$, ou seja, três vezes maior.

Se a escolarização define lugares a serem ocupados no mundo do trabalho e também valores salariais, não por acaso temos diferenças significativas entre as raças, no que tange à

21 Dados retirados do G1, em matéria publicada por Helton Simões Gomes, em 14/05/2018, intitulada "Brancos são maioria em empregos de elite e negros ocupam vagas sem qualificação". Disponível em $<$ https://g1.globo.com/economia/noticia/brancos-sao-maioria-em-empregos-deelite-e-negros-ocupam-vagas-sem-qualificacao.ghtml> e também de levantamento do IBGE, intitulado "Estatísticas de Gênero: indicadores sociais das mulheres no Brasil". Estudos e Pesquisas: Informação Demográfica e Socioeconômica, n. 38, 2018. Disponível em < https://agenciadenoticias.ibge.gov.br/media/com mediaibge/arquivos/9d6f4faeda1f 1fb7532be7a9240cc233.pdf >. Acesso em 25 jun. 2018.

22 Disponível em: https://agenciadenoticias.ibge.gov.br/agencia-sala-deimprensa/2013-agencia-de-noticias/releases/24857-pnad-continua-2018educacao-avanca-no-pais-mas-desigualdades-raciais-e-por-regiao-persistem. Acesso em 10 mai. 2020. 


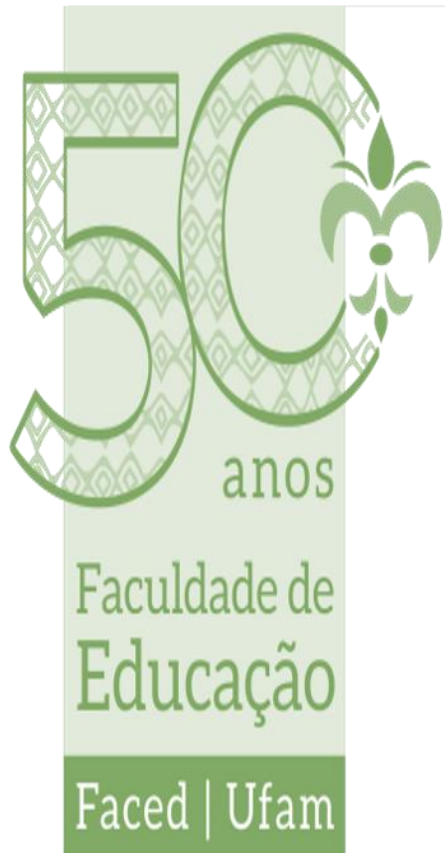

remuneração. Se, no passado, na sociedade escravista, leis foram criadas para negar o acesso à escolarização para negros africanos e seus descendentes, na República, a pobreza e a violência algumas das marcas do passado ainda presente - influenciam o distanciamento da escolarização. Nessa reflexão, adicionamos a essa equação da desigualdade, ao lado dos demais fatores sociais e históricos, o componente discursivo das representações. As condições sociopsicológicas de identificação e subjetivação têm o poder de reforçar e perpetuar, ao lado das condições materiais, o cenário de desigualdade social brasileiro, a partir do tolhimento do campo de possibilidades dos alunos possuidores de marcadores sociais negativos, em comparação com seus pares, num complexo jogo de hierarquias sociais conflitantes, intercaladas e sobrepostas.

O espaço escolar é parte significativa dessa produção discursiva - e de sua possível desarticulação -, por ser considerado local cujo objetivo é a reflexão e o debate, aspectos muitas vezes ausentes em outros espaços de sociabilidade. Nesse espaço, o discurso histórico ocupa lugar fundamental para a edificação de uma memória coletiva, que orienta posições-de-sujeito e comportamentos. Ainda hoje a tendência historicista influencia o olhar para o passado de professores, alunos e da sociedade em geral, resumindo o senso comum pelo qual se entende a História. No entanto, desde a década de 70 do século $\mathrm{XX}$, principalmente a partir dos estudos identificados com a Nova História Cultural e a Nova História Política, as vozes de diversos grupos sociais historicamente excluídos da ordem do discurso vêm conseguindo entrar no espaço da historiografia, como conteúdos relevantes para a análise histórica e sua transposição didática23.

Essa adesão foi fruto das demandas sociais latentes de maior representação desses mesmos grupos e possibilitou iluminar situações e jogos de poder até então naturalizados, reivindicando e resgatando memórias negligenciadas e, assim, contribuindo para a formação e o fortalecimento de novas identidades sociais. Assim,

${ }^{23}$ Sobre o conceito de transposição didática, ver MONTEIRO, 2007, p. 85. 


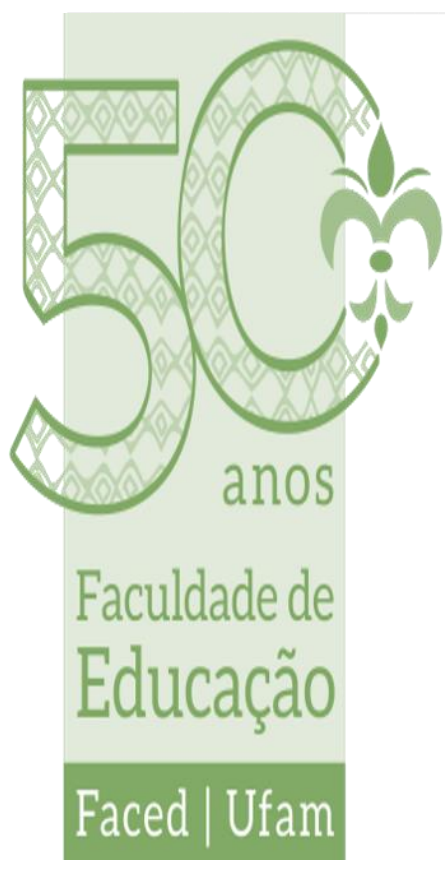

atualmente se tem contestado o antigo projeto educacional nacional, em que a escola deveria formar o cidadão brasileiro em sua perspectiva única e alinhada aos valores da classe dominante, omitindo as contradições sociais e gerando uma imagem irreal de sociedade pacífica e harmônica24. Diferença e ordem social não são conceitos antagônicos; pelo contrário, são inter-relacionais. A diferença é, afinal, fundamental ao sistema democrático e possui papel pedagógico, motivo pelo qual deva ser incorporada na dinâmica cotidiana da sala de aula. Segundo as Diretrizes Curriculares Nacionais Gerais da Educação Básica:

A educação destina-se a múltiplos sujeitos e tem como objetivo a troca de saberes, a socialização e o confronto do conhecimento, segundo diferentes abordagens, exercidas por pessoas de diferentes condições físicas, sensoriais, intelectuais e emocionais, classes sociais, crenças, etnias, gêneros, origens, contextos socioculturais, e da cidade, do campo e de aldeias (BRASIL, 2013, p. 27).

Aqui se encontra 0 potencial performativo positivo da educação. Não basta apenas afirmar e descrever a existência de diferentes identidades e culturas, apoiando-se em "um vago e benevolente apelo à tolerância e ao respeito para com a diversidade e a diferença" (SILVA, 2000, p. 73), pois, nessa perspectiva "a diferença e a identidade tendem a ser naturalizadas, cristalizadas, essencializadas" (SILVA, 2000, p. 73). Cairíamos, em vez disso, em um relativismo vazio, visto que essa postura não contesta e não busca alterar as classificações binárias arbitrárias e as relações de poder intrínsecas a elas, responsáveis por, ao longo das práticas sociais, reproduzirem e alimentarem as desigualdades, tanto materiais, quanto simbólicas. Questionar as representações identitárias históricas, evidenciando seu caráter artificial e político, passa então a não ser apenas possível, como, e principalmente, necessário. Para evitar esse problema, pensamos a construção de um conhecimento histórico escolar descentrado, nos moldes do

\footnotetext{
24 Para saber mais sobre esse antigo projeto e seu rompimento, ver Monteiro In: GOUVÊA, 2005, p. 444.
} 


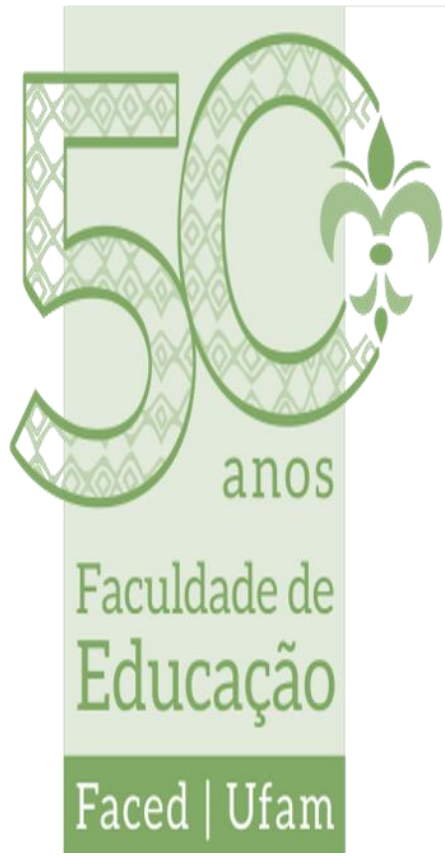

sentido que Natalie Davis confere ao termo ${ }^{25}$. A ideia da autora, que transpomos para $o(a)$ professor(a), é que ele(a) construa uma narrativa que seja social e geograficamente ampla. Primeiramente, introduzindo múltiplas vozes e oportunidades de fala aos sujeitos participantes de determinado acontecimento histórico, e não só aos sujeitos pertencentes à elite. Isso adiciona ao panorama narrativo todos aqueles indivíduos marginalizados das esferas hegemônicas de poder, tais como as mulheres, os negros, os indígenas, as classes com menor poder de renda.

Nessa perspectiva descentrada, aos negros devem ser dadas oportunidades narrativas protagonistas. Narrativas que devem ser construídas sem dirimir as diferentes formas de violência, às quais eram sujeitos esses grupos; elas nunca devem ser esquecidas ou suavizadas, mas não podem conferir-Ihes um caráter de inércia. Ao contrário - como bem demonstra a historiografia, desde a década de 80 do século $X X$-, o escravizado foi sujeito político, nem só vítima ou herói, ${ }^{26}$ agia e não somente reagia à sociedade escravista. Do mesmo modo, o faz o indivíduo negro da sociedade atual.

Ampliando não só os grupos sociais representados no discurso histórico, mas também a forma como aparecem em sua diversidade de experiências, ou seja, tratando-os como identidades inteiras capazes de estabelecer relações e formular criativamente seus próprios destinos, dentro dos seus campos de ação particulares, torna-se possível a construção de um pensamento reflexivo sobre a realidade.

Ao ver a identidade como uma questão de "tornarse", aqueles que reivindicam a identidade não se limitariam a ser posicionados pela identidade: eles seriam capazes de posicionar a si próprios e de reconstruir e transformar as identidades históricas, herdadas de um suposto passado comum (WOODWARD In: SILVA, 2000, p. 28).

25 DAVIS, 2011, p. 188-2.

26 Sobre a questão de o escravizado não ser sempre vítima ou herói, mas ao contrário, um complexo sujeito na sociedade do século XIX ver: SILVA, Eduardo; REIS, João José. Negociação e Conflito: a resistência negra no Brasil escravista. São Paulo: Companhia das Letras, 1989. 


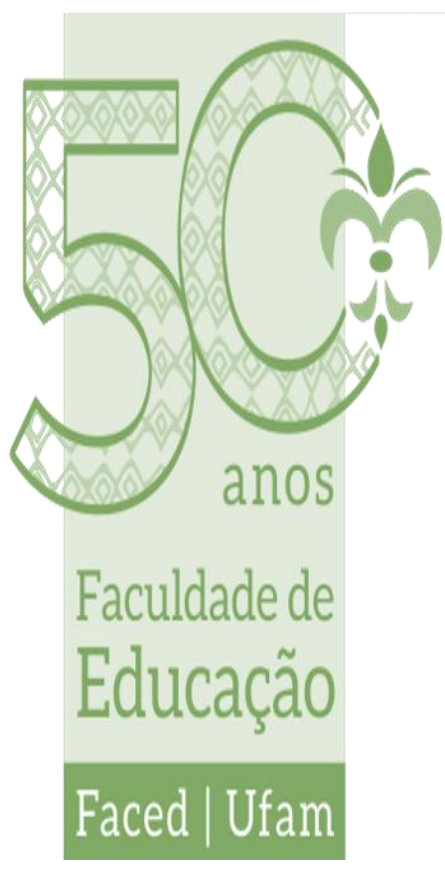

As mudanças históricas, dessa forma, podem aparecer não mais como ameaças à coesão social, mas sim como qualidades humanas de amplo potencial performativo. A partir disso, os discentes obteriam os subsídios críticos necessários para a tomada, se assim for desejado, de uma atitude de transformação social em direção a um Brasil menos desigual. Em um mundo cada vez mais dinâmico e veloz, tentativas anacrônicas de imobilidade e estagnação não refletem, mais do que nunca, as pluralidades identitárias e os anseios sociais.

\section{CONSIDERAÇÕES FINAIS}

Analisar dificuldades, atitudes e projetos de lei nos permite historicamente refletir o quanto a educação é significativa para a sociedade brasileira. Contudo, o espaço escolar não contempla a todos os indivíduos equitativamente. Nos dias atuais, ainda vemos, nos diferentes meios de informação, reivindicações por melhor educação: por acesso e permanência. Assim como aqueles homens libertos reivindicavam educação para seus filhos, em abril de 1889 , muitos pais, na sociedade brasileira atual, desejam que seus filhos tenham acesso à educação nos seus diferentes níveis. Mais do que acesso, permanência! Historicamente, que memórias relativas à educação foram construídas? Quais desejamos construir?

O discurso histórico escolar é fundamental para a edificação de uma memória coletiva, que orienta posicionamentos e comportamentos, assim como para a construção das identidades e diferenças dos discentes. Construído por meio de representações que corroboram ou confrontam visões identitárias presentes na estrutura simbólica de nossa cultura, ele atua como prática social edificadora de significado. Essas representações podem ou não ganhar força no meio social e se tornar expressão da própria realidade, através do potencial performativo do discurso. Sua ausência, ou presença viciada e limitada, nesse sentido, também colabora para a formação de uma autoimagem adulterada dos estudantes. "O desconhecimento do passado significa sofrê-lo com 


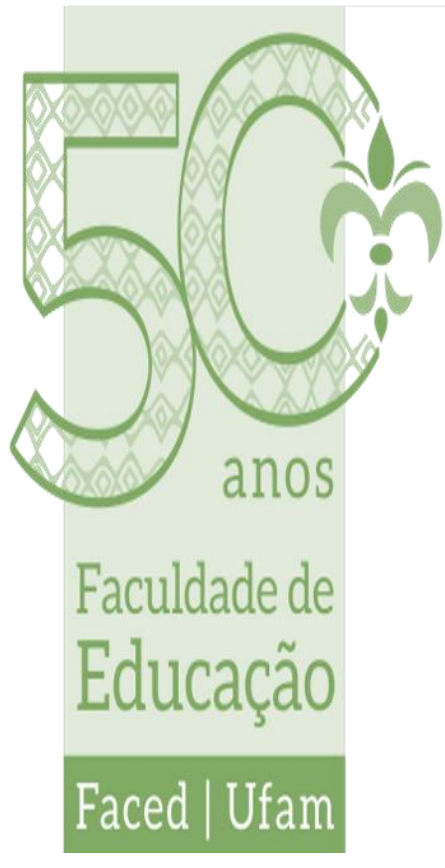

passividade, pois alcançar a dimensão da própria história pressupõe a tomada de consciência do que se é e do que se foi, rompendo com a perspectiva da alienação" (LIMA, 2014, p. 56).

A forma de se representar os atores sociais nos diversos acontecimentos históricos, produzidos tanto no ambiente escolar quanto no ambiente cultural e acadêmico, faz, portanto, toda a diferença para a apropriação desse conhecimento, suas permanências no imaginário social e na formulação das identidades. Nesse sentido, a teoria social do discurso nos ajuda a compreender que não podemos fugir das classificações, no entanto, podemos ressignificá-las e assumi-las, tendo a consciência de que elas são dinâmicas e construídas e, portanto, não precisamos nos prender a esquemas que não mais satisfazem nossas subjetividades, incorporando, assim, a mutabilidade do termo tornar-se. "Isso não significa negar que a identidade tenha um passado, mas reconhecer que, ao reivindicá-la, nós a reconstruímos e que, além disso, o passado sofre uma constante transformação" (WOODWARD In: SILVA, 2000, p. 28). O caminho não é mais a harmonização dos conflitos sociais, mas sua exposição e - o mais importante - uma tomada de postura crítica em relação a eles. A convivência positiva com a diferença não pode ser negligenciada num sistema educacional e nacional que se afirme democrático.

A diferença pode ser construída negativamente por meio da exclusão ou da marginalização daquelas pessoas que são definidas como "outros" ou forasteiros. Por outro lado, ela pode ser celebrada como fonte de diversidade, heterogeneidade e hibridismo, sendo vista como enriquecedora [...] (SILVA, 2000, p. 50).

Nesse contexto, uma narrativa histórica descentrada, calcada na repetição da diferença enquanto elemento central da vida em sociedade, e polo norteador das múltiplas identidades, pode ajudar no processo de desconstrução de representações negativas, (re)produtoras de desigualdades sociais. O discurso histórico escolar atual deve possibilitar ao aluno sua autonomia na construção de sentidos no mundo por meio de representações justas. Se o objetivo 


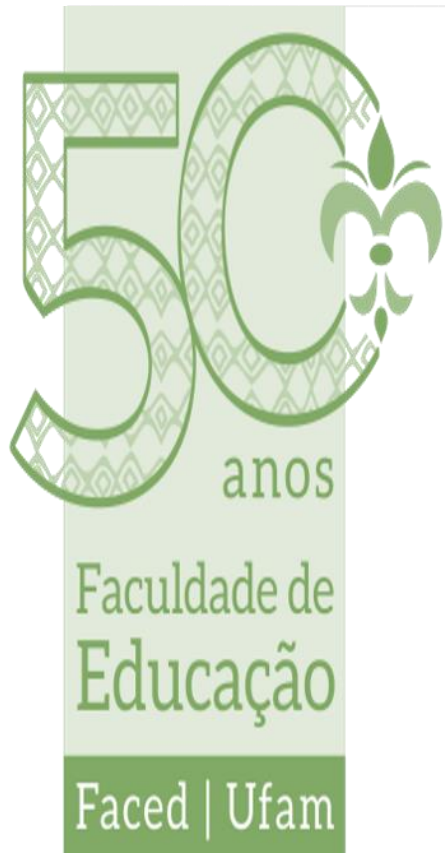

da educação é a formação plena do cidadão, faz-se necessário que este saiba se posicionar historicamente na sociedade e seja capaz de escolher seus projetos de futuro dentre um amplo campo de possibilidades, não mais limitados por cruéis amarras identitárias.

Afinal... aprender História é aprender sobre nós
mesmos. É aprender sobre a diversidade das
experiências humanas através dos tempos e nos
diferentes lugares. É aprender que o homem é o
conjunto de suas práticas como sujeito,
protagonista, e ao mesmo tempo sujeito à sua
circunstância, no fazer da cultura. Aprender que o
diferente nos homens de qualquer tempo e lugar
nos é familiar porque a humanidade é uma, mas a
cultura é plural (MONTEIRO In: GOUVÊA, 2005, p.
448).

\section{REFERÊNCIAS}

BRASIL, Diretrizes Curriculares Nacionais Gerais da Educação Básica/ Ministério da Educação. Secretária de Educação Básica. Diretoria de Currículos e Educação Integral. - Brasília: MEC, SEB, DICEI, 2013. Disponível em $<$ http://portal.mec.gov.br/index.php?option=com docman\&view=dow nload\&alias=13448-diretrizes-curiculares-nacionais-2013pdf\&ltemid=30192>. Acesso em 11 jun. 2018.

CERRI, Luís Fernando. Ensino de história e consciência histórica. Rio de Janeiro: Editora FGV, 2011.

DAVIS, Natalie Z. Descentering history: local stories and cultural crossings in a global world. History and Theory, 50, may 2011, p. 188-202.

FAIRCLOUGH, Norman; MAGALHÃES, Izabel. Discurso e mudança social. Brasília, DF: Ed. Universidade de Brasília, 2001, $316 \mathrm{p}$.

FONSECA, Thais Nivia de Lima e. História \& ensino de História. 4.ed. Belo Horizonte: Autêntica Editora, 2017.

FOUCAULT, Michel. A ordem do discurso: aula inaugural no Collège de France. São Paulo: Edições Loyola, 24. ed, 2014.

GOUVÊA, M. De F.; BICALHO, M. F. B.; SOIHET, R. Culturas políticas: ensaio de história cultura, história política e ensino de história. Rio de Janeiro: FAPERJ: Mauad, 2005.

HALL, Stuart. A identidade cultural na pós-modernidade. 11. ed. Rio de Janeiro: DP\&A, 2006. 


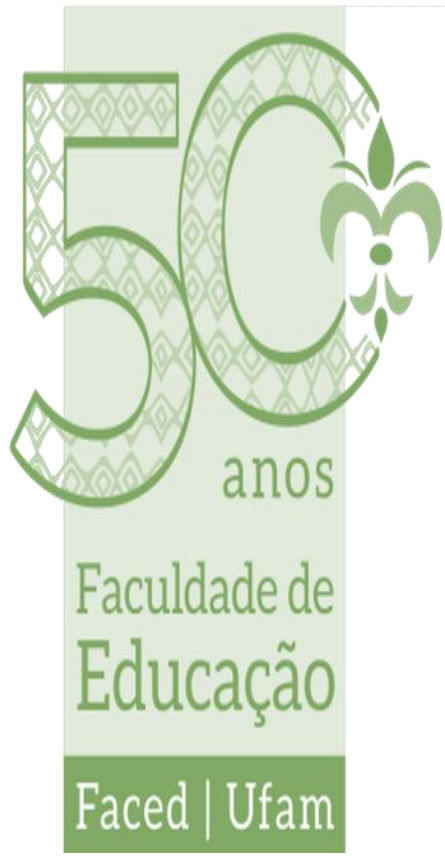

LIMA, Maria. "Consciência Histórica e educação histórica: diferentes noções, muitos caminhos" In: MAGALHÃES, Marcelo, [et al] (org.). Ensino de história: usos do passado, memória e mídia. Rio de Janeiro: Editora FGV, 2014, p. 53-76.

MONTEIRO, Ana Maria. "Os saberes que ensinam: o saber escolar" In: . Professores de História: entre saberes e práticas. Rio de Janeiro: ed. Mauad X, 2007, cap. 3, p. 81-111.

RIBEIRO, Djamila. O que é lugar de fala? Belo Horizonte: Letramento: Justificando, 2017.

SILVA, Tomaz Tadeu da Silva (org.); HALL, Stuart; WOORWARD, Kathryn. Identidade e diferença: a perspectiva dos estudos culturais. Petrópolis, RJ: Vozes, 2000.

SLENES, Robert. "Eu venho de muito longe, eu venho cavando": jongueiros cumba na senzala centro-africana, In: LARA, Silva e PACHECO, Gustavo (orgs.). Memória do Jongo. Rio de Janeiro: Folha Seca, 2007.

VIANA, lamara da Silva; GOMES, Flávio dos Santos \& RIBEIRO NETO, Alexandre. "Escritos insubordinados entre escravizados e libertos no Brasil". Estudos Avançados, volume 33, Instituto de Estudos Avançados/USP, 2019, pp. 55-177.

Artigo recebido em: 31 de maio de 2020 Aceito para publicação em: 20 de junho de 2020 